\title{
Configurações
}

\section{Género, sexualidade e afetos}

\section{Ana Maria Brandão e José Resende}

\section{OpenEdition}

\section{Journals}

\section{Edição electrónica}

URL: http://journals.openedition.org/configuracoes/2570

DOI: 10.4000/configuracoes. 2570

ISSN: 2182-7419

\section{Editora}

Centro de Investigação em Ciências Sociais

\section{Edição impressa}

Data de publição: 30 Junho 2015

Paginação: 5-7

ISBN: 1646-5075

ISSN: 1646-5075

\section{Refêrencia eletrónica}

Ana Maria Brandão e José Resende, « Género, sexualidade e afetos », Configurações [Online], 15 | 2015, posto online no dia 01 setembro 2015, consultado o 03 maio 2019. URL : http://

journals.openedition.org/configuracoes/2570; DOI : 10.4000/configuracoes.2570

Este documento foi criado de forma automática no dia 3 Maio 2019

(c) CICS 


\title{
Género, sexualidade e afetos
}

\author{
Ana Maria Brandão and José Resende
}

1 Este número da Configurações reúne um conjunto de artigos dedicados ao estudo do género, da sexualidade e dos afetos. Estando em causa fenómenos distintos, existe entre eles uma relação de influência mútua, cujo nexo explicativo remete, frequentemente, para a ordem de género. A feminilidade e a masculinidade normativas continuam, enfim, a interferir naquilo que somos e naquilo que fazemos nos domínios sexual e afetivo. É a compreensão explícita ou tácita deste facto que leva à gestão mais ou menos cuidadosa das formas como nos mostramos e exprimimos em público, frequentemente contrastantes com as que adotamos em privado. Há, porém, diferentes maneiras de experimentar e entender essa relação, umas conformando-se aos modelos normativamente aceites, outras situadas - por vezes, pretendendo mesmo situar-se nas margens, em qualquer caso traduzindo sempre a interseção de variáveis como a classe, a pertença geracional, a pertença a subculturas particulares, apenas para referir algumas. É destas múltiplas determinações que tratam os textos aqui apresentados.

O artigo que abre este número, da autoria de Pedro Boia, Lígia Ferro e João Teixeira Lopes, propõe uma proposta analítica dos processos de construção das identidades de género no contexto das subculturas associadas às festas de música eletrónica de dança em Portugal. Concebido a partir de uma investigação empírica, o modelo apresentado centra-se no caso das mulheres embora não se cinja a ele, sugerindo formas de operacionalização do fenómeno do clubbing que permitam dar conta da sua diversidade interna, nomeadamente no que respeita às diferentes construções do género que aí podem ser encontradas. Variáveis como a classe social, a etnia, a estruturação interna do clubbing, as trajetórias biográficas e de socialização, entre outras, são assim mobilizadas, revelando o carácter multidimensional e compósito por vezes, mesmo paradoxal dos fenómenos identitários, ilustrado pela presença de diferentes modos de ser mulher e sublinhando a importância da agência no seu processo de construção.

3 Centrando-se, por sua vez, no caso dos homens e das masculinidades, Luís Santos dá, seguidamente, conta dos modos como estes regulam as suas emoções e os seus afetos. Apesar das mudanças operadas ao nível das relações sociais de género nas últimas 
décadas, a masculinidade hegemónica continua a assentar largamente no autocontrolo e na racionalidade e é com esse ideal que a generalidade dos homens se confronta. Segundo o autor, as reflexões destes sobre a gestão das emoções e dos afetos articulam-se em torno de duas construções discursivas - designadas de Máscara para homem e Homens por detrás da máscara que sublinham a disjunção entre a imagem de si que se apresenta em público e que procura conformar-se às expectativas dominantes e a que existe para si onde emoções, afetos e sentimentos são vividos, muitas vezes, em isolamento. Assim, se o texto anterior dá conta da autonomia relativa do ator, este revela-nos a outra face da ordem social a dos efeitos coercivos da ordem de género.

4 É também a gestão dos afetos no espaço público que Tânia Cristina Machado discute no seu artigo, desta vez tomando como objeto empírico casais de mulheres com filhos. Também aqui se fazem sentir os efeitos da ordem, especialmente da feminilidade hegemónica, intimamente associada à heterossexualidade normativa. Com efeito, se a autora consegue identificar duas estratégias mobilizadas por esses casais nas interações públicas uma de ocultação, caracterizada pela ausência de manifestações afetivas fora do espaço privado; outra, de afirmação, que se configura como uma transgressão das fronteiras simbólicas do espaço público através da visibilidade das manifestações de afeto, é, uma vez mais, a consciência da ordem e das consequências da sua rutura que predomina. A adoção de uma ou outra estratégia é, igualmente, atravessada pela pertença geracional, pela classe social de origem e pela configuração das redes de sociabilidade, o que sublinha, como já salientado por Boia, Ferro e Lopes, a necessidade de atender aos efeitos cruzados das variáveis sociodemográficas na análise dos fenómenos do género e da sexualidade.

5 É ainda sobre os efeitos coercivos da ordem que nos fala António Fernando Cascais num texto onde reflete sobre o padrão estético-erótico de beleza e juventude que rege o habitus homossexual. Caracterizado como geracionista, eugenista e melhorista pelo autor, esse padrão teria um carácter mais compensatório do que emancipatório daquilo que designa como "vergonha fundacional da identidade homossexual". Entre outras razões, porque traduz, sob certos aspetos, uma aquiescência aos traços constitutivos da masculinidade hegemónica, tornando, por assim dizer, a figura do gay mais "palatável" para a sociedade dominante. Mas também porque, impondo-se como modelo normativo da subjetivação gay, produz os seus próprios mecanismos de exclusão enquanto ideal inalcançável, assim reforçando a ideia de menoridade, de fracasso, de vergonha entre aqueles que não se the podem ou querem conformar. A este estado de coisas, contrapõe Cascais uma outra visão que passa pela mobilização ativa de formas alternativas de subjetivação, de "malogro" da homonormatividade, que permitam uma efetiva libertação face às lógicas dominantes do poder.

6 Encerram este número da Configurações duas recensões, da autoria de Ana Maria Brandão e Tahiana Meneses Alves. A primeira discute a origem, o desenvolvimento e os contributos fundamentais dos estudos do género; a segunda centra-se na análise da relação entre doença mental e género. Embora não estejam propriamente em causa obras "novas", ambas constituem introduções fundamentais e particularmente operacionais nas temáticas respetivas. 


\section{AUTHORS}

\section{ANA MARIA BRANDÃO}

CICS - Universidade do Minho

Prof. Auxiliar do Departamento de Sociologia do Instituto de Ciências Sociais da Universidade do Minho e Investigadora Integrada do Centro Interdisciplinar de Ciências Sociais - Polo UMinho (CICS.NOVA.UMinho). Endereço de correspondência: CICS.NOVA.UMinho Campus de Gualtar, 4710-057 Braga

anabrandao@ics.uminho.pt

JOSÉ RESENDE

CICS - Universidade Nova de Lisboa

Prof. Associado com Agregação da Faculdade de Ciências Sociais e Humanas da Universidade de Lisboa e Investigador integrado do CICS.NOVA. Endereço de correspondência: Av. Berna 26 C, 1069-061 Lisboa

josemenator@gmail.com 